\title{
KERAHASIAAN BANK SUATU TINJAUAN DALAM ATURAN HUKUM PERBANKAN SYARIAH DI INDOESIA
}

\author{
Miftah Idris \\ Universitas Muhammadiyah Luwuk Banggai \\ Email : miftahidrei@rocketmail.com
}

\begin{abstract}
Islamic Banking is part of the financial and payment system of a country and its existence depends absolutely on the confidence of the customers who entrust their deposits in the Islamic Banking, so the bank secrecy is necessary to maintain it. Bank secrecy as defined under the Act is everything related to the financial and other matters of bank customers in the ordinary course of banking world shall be kept confidential in this case Islamic banking. In this paper there would discuss how was the actual secrecy Islamic bank in Indonesia in accordance with the applicable law and how it was applied in the field. This was written to determine the scope of bank secrecy in Islamic banking and exceptions set out in secrecy banks in Islamic banking in Indonesia.
\end{abstract}

Keywords: Bank Secrecy, the Rule of Law, and the Indonesian Islamic Banking.

\begin{abstract}
Abstrak
Perbankan syariah adalah bagian dari sistem keuangan dan pembayaran suatu negara dan keberadaannya bergantung sepenuhnya pada kepercayaan pelanggan yang mempercayakan simpanan mereka di Perbankan Islam, sehingga kerahasiaan bank diperlukan untuk mempertahankannya. Bank, sebagaimana didefinisikan oleh UndangUndang, adalah segala sesuatu yang berkaitan dengan keuangan dan hal-hal lain dari pelanggan dalam kehidupan biasa di dunia perbankan, dan dalam hal ini rahasia untuk perbankan Islam. Dalam makalah ini akan ada diskusi tentang kerahasiaan sebenarnya bank syariah di Indonesia. Ini ditulis untuk menentukan ruang lingkup kerahasiaan bank dalam perbankan syariah dan pengecualian bank kerahasiaan dalam perbankan syariah di Indonesia.
\end{abstract}

Kata Kunci : Rahasia Bank, The Rule of Law, Bank Perbankan Syariah

\section{PENDAHULUAN}

Menurut sejarah, penerapan keraha-siaan bank sama tuanya dengan perkembangan perbankan sendiri. Bahkan sudah ada sejak 4000 tahun yang lalu di Babylonia sebagaimana tercantum dalam Code of Hamourabi. Aturan kerahasiaan bank yang dalam perkembangannya juga diakui sebagai bagian dari hak asasi manusia yang berfungsi untuk melindungi rahasia pribadi orang tersebut (right of privacy) serta keuangannya (financial privacy). Bahkan mengenai rahasia bank ini di berbagai negara 
telah masuk dalam konstitusi atau undang-undang yang tujuannya adalah untuk menciptakan kepercayaan masyarakat yang menyimpan uangnya di bank. ${ }^{1}$

Pada zaman abad pertengahan keten-tuan semacam kerahasiaan bank itu telah diatur pada peraturan perundangan, bahkan di kerajaan Jerman pada saat itu telah diatur dalam Kitab Undang-Undang Hukum Per-data. Dengan berkembanganya perdagangan dan ambruknya feodalisme dalam pertarungan yang semakin sengit untuk memperjuangkan hak-hak individu, kepercayaan kepada kebijaksanaan lembaga perbankan untuk merahasiakan keterangan-keterangan mengenai soal-soal keuangan, dan pribadi nasabah-nasabahnya menjadi suatu kebu-tuhan yang tidak bisa ditawar-tawar lagi bagi perlindungan hak milik pribadi dan bagi kalangan praktik perdagangan. Menjelang pertengahan abad ke-19, boleh dikatakan semua pemerintah di Eropa Barat telah mensahkan asas kerahasiaan bank, dan semenjak itu undang-undang serupa telah diberlakukan di setiap negara yang menghendaki sistem perbankan yang tertib. ${ }^{2}$ Tidak jauh berbeda dengan yang ada di negara-negara lain, di Indonesia, tugas bank dalam mencapai tujuan pembangunan nasional yaitu mewujudkan masyarakat yang adil dan makmur berdasarkan Pancasila dan Undang-Undang Dasar 1945. Selain itu, bank mempunyai peran yang sangat penting yang perannya diatur dalam aturan hukum perbankan yang ada di Indonesia. Sebab, sebagai salah satu motor penggerak pembangunan bangsa, lembaga perbankan mem-punyai peran yang sangat strategis karena bank mempunyai fungsi intermediasi untuk menghimpun dana dari masyarakat sebagai nasabah dalam bentuk simpanan dan menya lurkan kembali dana tersebut dalam bentuk pinjaman kepada masyarakat yang mem-butuhkannya. Bank diharap dapat menyerasikan, menyelaraskan menyeimbangkan unsur pemerataan pembangunan dan hasilhasilnya, pertumbuhan ekonomi dan stabi-litas nasional yang pada akhirnya mengarah kepada peningkatan taraf hidup masyarakat banyak. Bank di Indonesia merupakan

\footnotetext{
${ }^{1}$ Heru Supraptomo, 2005, Terobosan Hukum dalam Rahasia Bank, artikel dalam Jurnal Hukum Bisnis, Yayasan Pengembangan Hukum Bisnis, Jakarta: hlm. 26.

${ }^{2}$ Muhammad Djumhana, 1996, Rahasia Bank (Ketentuan dan Penerapannya) di Indonesia, PT Citra Aditya Bakti, Bandung: hlm. 112.
} 
bagian dari sistem keuangan dan sistem pembayaran suatu negara. Pada era globalisasi, bank juga telah menjadi bagian dari sistem keuangan dan sistem pembayaran dunia. Mengingat hal yang demikian itu, maka begitu suatu bank telah memperoleh ijin berdiri dan beroperasi dari otoritas moneter dari negara yang bersangkutan, bank tersebut menjadi milik masyarakat. Oleh karena itu eksistensinya bukan saja hanya harus dijaga oleh para pemilik bank itu sendiri dan pengurusnya, tetapi juga oleh masyarakat nasional dan global.

Bank merupakan lembaga keuangan yang eksistensinya tergantung mutlak pada kepercayaan dari para nasabahnya yang mempercayakan dana simpanan mereka pada bank. Oleh karena itu bank sangat berkepentingan agar tingkat kepercayaan masyarakat, yang telah maupun yang akan menyimpan dananya, terpelihara dengan baik dalam tingkat yang tinggi. Mengingat bank adalah bagian dari sistem keuangan dan sistem pembayaran, yang masyarakat luas berkepentingan atas kesehatan dari sistem-sistem tersebut, sedangkan keper-cayaan masyarakat kepada bank merupakan unsur paling pokok dari eksistensi suatu bank, maka terpeliharanya kepercayaan masyarakat kepada perbankan adalah juga kepentingan masyarakat banyak. ${ }^{3}$

Meskipun demikian, untuk membukti-kan eksistensi suatu bank juga dapat dilihat dengan mencari bagaimana kerahasiaan bank tersebut, namun pada umumnya sistem kerahasiaan bank yang ada di Indonesia hampir semuanya sama persis dalam pene-rapannya baik itu perbankan konvensional dan perbankan syariah. Bagaimana tidak, kerahasiaan setiap bank-bank tersebut adalah suatu keharusan yang ada dalam aturan setiap bank. Dengan adanya ketentuan kerahasiaan bank ini menimbul-kan kesan bagi masyarakat, bahwa bank bisa jadi sengaja merahasiakan sumber keuangan nasabahnya yang tidak sehat dari sorotan masyarakat yang ingin mencari tahu. Sehingga selama ini timbul kesan bahwa dalam sistem perbankan itu sendiri timbul kesan bahwa bank bersembunyi di balik kerahasiaan bank untuk melindungi kepen-

\footnotetext{
${ }^{3}$ Andrian Sutedi, 2007, Hukum Perbankan: Suatu Tinjauan Pencucian Uang, Merger, Likuidasi, dan Kepailitan, Sinar Grafika, Jakarta: hlm. 1.
} 
tingan nasabahnya yang belum tentu benar. Persepsi yang berbeda dari masyarakat akan perbankan syariah justru berbeda dengan konvensional, bagaimana tidak, sebab nilai yang dibawa oleh perbankan syariah adalah nilai-nilai yang terkandung dalam Islam yang jauh dari nilai kemudharatan secara prinsipnya. Sehingga masyarakat Indonesia yang dominan Islam kebanyakan berang-gapan bahwa dengan sumber keuangan yang sehat dari nasabah tersebut sebaiknya disimpan di bank yang memiliki sistem kerahasiaan bank yang sehat juga. Terlepas dari keyakinan tersebut, jika bank benar-benar melindungi kepentingan nasabahnya yang jujur dan bersih, maka hal itu merupakan suatu keharusan dan kepatutan. Sebab, ketentuan kerahasiaan bank merupakan suatu hal yang sangat penting bagi nasabah penyimpan dan simpanannya maupun kepentingan bagi bank itu sendiri. ${ }^{4}$

Meskipun demikian, Ketentuan kera-hasiaan bank yang ada di Indonesia diatur di dalam Undang-Undang Perbankan, selanjut-nya disebut UUP. Dengan adanya undang-undang tersebut, bertujuan untuk meng-hindari terjadinya penyalahgunaan keuangan nasabah, maka dibuatlah aturan khusus yang melarang bank untuk memberikan informasi tercatat kepada siapapun berkaitan dengan keadaan keuangan nasabah, simpanan dan penyimpanannya sebagaimana diatur dalam Undang-Undang Nomor 7 Tahun 1992 tentang Perbankan sebagaimana diubah dengan Undang-Undang Nomor 10 Tahun 1998 kecuali dalam hal-hal tertentu yang disebutkan secara tegas di dalam undang-undang tersebut. Terkait dalam aturan ter-sebut, pelanggaran terhadap ketentuan kera-hasiaan bank juga merupakan suatu tindak pidana dan pihak-pihak yang tidak meme-gang teguh ketentuan kerahasiaan bank tersebut dapat dikenakan sanksi pidana.

Bagi perbankan syariah, ketentuan rahasia bank diatur secara khusus dalam ketentuan Pasal 41 sampai dengan Pasal 49 Undang-Undang Nomor 21 Tahun 2008 tentang Perbankan Syariah. Namun, pada Pasal 42 sampai Pasal 48 Undang-Undang

\footnotetext{
${ }^{4}$ Hermansyah, 2005, Hukum Perbankan Nasional Indonesia, Kencana, Jakarta: hlm. 109-110.
} 
Perbankan Syariah, selanjutnya disebut UUPS, mengatur mengenai pengecualian atas berlakunya ketentuan kerahasiaan bank yang tidak jauh berbeda dengan apa yang diatur dalam Undang-Undang Perbankan. Sebab pada dasarnya pengaturan ketentuan kerahasiaan bank dalam kegiatan usaha perbankan tidak jauh berbeda dengan pengaturan ketentuan rahasia bank dalam kegi-atan usaha perbankan konvensional sebagaimana yang tertuang dalam Undang-Undang Perbankan.

\section{KERAHASIAAN BANK DI INDONESIA}

Menurut Sutan Remy Sjahdeini, ${ }^{5}$ Bank adalah suatu lembaga keuangan yang eksistensinya tergantung mutlak pada keper-cayaan dari para nasabah yang mempercayakan dan dan jasa-jasa lain yang dilakukan mereka melalui bank pada khususnya dan dari masyarakat luas pada umumnya. Oleh karena itu, bank sangat berkepentingan agar kadar kepercayaan masyarakat, yang telah maupun yang akan menyimpan dananya, maupun yang telah atau akan menggunakan jasa-jasa bank lainnya, terpelihara dengan baik dalam tingkat yang tinggi. Mengingat bank adalah bagian dari sistem keuangan dan sistem pembayaran, yang masyarakat luas ber-kepentingan atas kesehatan dari sistem-sistem tersebut, sedangkan kepercayaan masyarakat kepada bank merupakan unsur paling pokok dari eksistensi suatu bank, maka terpeliharanya kepercayaan masya-rakat kepada perbankan adalah juga kepen-tingan masyarakat banyak.

Sedangkan dalam istilah Muhammad Djumhana bahwa rahasia bank adalah segala sesuatu yang berhubungan dengan keuangan dan hal-hal lain dari nasabah bank yang menurut kelaziman dunia perbankan tidak boleh secara terbuka diungkapkan kepada pihak masyarakat. Dalam hubungan ini yang menurut kelaziman wajib dirahasiakan oleh bank, adalah seluruh data dan informasi mengenai segala sesuatu

\footnotetext{
5 Sutan Remy Sjahdeini, 2006, Rahasia Bank: Berbagai Masalah di Sekitarnya, dalam Hukum Perbankan, Program Pascasarjana Universitas Indonesia, Jakarta: hlm. 26-27
} 
yang berhubungan dengan keuangan, dan hal-hal lain dari orang, dan badan yang diketahui oleh bank karena kegiatan usahanya. ${ }^{6}$

Selain itu, Menurut Munir Fuady me-miliki interpretasi yang berbeda mengenai rahasia bank, menurutnya bahwa rahasia bank adalah hubungan antara bank dengan nasabah ternyata tidaklah seperti hubungan kontraktual biasa. Akan tetapi dalam hubungan tersebut terdapat pula kewajiban bagi bank untuk tidak membuka rahasia nasabahnya kepada pihak lain manapun kecuali jika ditentukan lain oleh perundangundangan yang berlaku. Hal ini dinamakan rahasia bank. Dengan demikian, istilah rahasia bank mengacu pada rahasia dalam hubungan antara bank dengan nasabahnya. ${ }^{7}$

Dalam UUP sendiri, kerahasiaan bank diartikan bahwa segala sesuatu yang berhubungan dengan keterangan nasabah penyimpan dan simpanannya. ${ }^{8}$ Sedangkan dalam UUPS kerahasiaan bank diartikan bahwa segala sesuatu yang berhubungan dengan keterangan mengenai nasabah penyimpan dan simpanannya serta nasabah dan investor dan investasinya. ${ }^{9}$

Pada dasarnya terdapat perbedaan dari pengertian rahasia bank dari peraturanperaturan perundang-undangan mulai dari Undang-Undang Nomor 14 Tahun 1967 hingga Undang-undang yang masih berlaku sekarang. Dibawah ini kutipan beberapa pengertian rahasia bank tersebut, yaitu: ${ }^{10}$

1) Menurut Undang-Undang Nomor 14 Tahun 1967 tentang Pokok-pokok Perbankan, sebagaimana dalam Pasal 36 menyatakan bahwa:

"Yang dimaksudkan dengan rahasia bank adalah segala sesuatu yang berhubungan dengan keuangan dan lain-lain dari nasabah menurut kelaziman dunia perbankan perlu dirahasiakan."

\footnotetext{
${ }^{6}$ Muhammad Djumhana, 1996, Rahasia Bank (Ketentuan dan Penerapannya) di Indonesia, PT Citra Aditya Bakti, Bandung: hlm. 1

${ }^{7}$ Munir Fuady, 1999, Hukum Perbankan Modern Buku Kesatu, PT Citra Aditya Bakti, Bandung: hlm. 80

${ }^{8}$ Pasal 1 Angka (28) Undang-Undang Nomor 10 Tahun 1998 tentang Perubahan Atas UndangUndang Nomor 7 Tahun 1992 tentang Perbankan

${ }^{9}$ Pasal 1 Angka (14) Undang-Undang Nomor 21 Tahun 2008 tentang Perbankan Syariah.

${ }^{10}$ Muhamad Djumhana, 2012, Hukum Perbankan di Indonesia, Citra Aditya Bakti, Cetakan ke VI, hlm. 158 .
} 
2) Selanjut menurut Pasal 1 Angka 16 Undang-Undang Nomor 7 Tahun 1992 tentang Perbankan, menyatakan bahwa:

"Rahasia bank adalah segala sesuatu yang berhubungan dengan keuangan dan lain-lain dari nasabah bank yang menurut kelaziman dunia perbankan wajib dirahasiakan."

Dari pengertian di atas, Muhamad Djumhana ${ }^{11}$ menafsirkan bahwa ternyata juga masih dirasakan sangat luas karena ada kalimat "hal-hal lain dari nasabah bank yang menurut kelaziman dunia perbankan wajib dirahasiakan". Selanjutnya bahwa dalam penjelasannya disebutkan yang dimaksud dengan menurut kelaziman hal-hal lain yang wajib dirahasiakan oleh bank, yaitu seluruh data dan informasi mengenai segala sesuatu yang berhubungan dengan keuangan, dan hal-hal lain dari orang, dan badan yang diketahui oleh bank karena kegiatan usahanya.

3) Menurut Undang-Undang Nomor 10 Tahun 1998 tentang Perubahan atas UndangUndang Nomor 7 Tahun 1992 tentang Perbankan, Pasal 1 Angka 28 menyatakan bahwa:

"Rahasia bank adalah segala sesuatu yang berhubungan dengan keterangan mengenai nasabah penyimpan dan simpanannya."

4) Pasal 1 Angka 14 Undang-undang No 21 tahun 2008 tentang Perbankan Syariah, menyatakan bahwa :

"Rahasia bank adalah segala sesuatu yang berhubungan dengan keterangan mengenai nasabah penyimpan dan simpanannya serta nasabah investor dan investasinya."

Berbicara mengenai teori-teori rahasia bank, maka ada ketentuan megenai rahasia bank itu sehingga kemudian menimbulkan kesan bagi masyarakat (nasabah) bahwa bisa juga bahwa bank sendiri sengaja untuk menyembunyikan keadaan

\footnotetext{
${ }^{11}$ Ibid, hlm. 159
} 
keuangan yang tidak sehat dari nasabah debitur, baik orang perorangan, atau perusahaan yang sedang menjadi sorotan masyarakat. ${ }^{12}$

Sehingga dengan demikian terkadang kepercayaan kepada bank sangat diragukan. Akan tetapi terdapat juga ketentuan bahwa karena rahasia bank yang merupakan suatu hal yang sangat penting bagi nasabah penyimpan maupun simpanannya serta juga bagi kepentingan bank itu sendiri. Sehingga dengan demikian maka rahasia bank juga diperlukan.

Teori-teori rahasia bank dapat diarti-kan bahwa suatu bank wajib merahasiakan berbagai informasi nasabahnya itu dengan ketentuan yang bersifat mutlak. Selanjutnya dikemukakan dua teori tentang rahasia bank, antara lain: ${ }^{13}$

1) Teori rahasia bank yang bersifat mutlak (Absolutely Theory). Maksud dari teori ini bahwa bank mempunyai kewajiban untuk menyimpan rahasia atau kete-ranganketerangan mengenai nasabah-nya yang diketahui bank karena kegiatan usahanya dalam keadaan apapun juga, dalam keadaan biasa atau dalam keadaan luar biasa. Teori ini menon-jolkan kepentingan individu dan masyarakat yang sering terabaikan.

2) Teori rahasia bank yang bersifat relatif (Relative Theory). Menurut teori ini, bank diperbolehkan untuk membuka rahasia atau memberikan keterangan nasabah mengenai nasabahnya, jika untuk kepentingan yang mendesak, misalnya untuk kepentingan negara atau kepentingan hukum.

Artinya bahwa adanya pengecualian dari rahasia nasabah itu untuk memungkinkan bank membuka informasi itu yang berkaitan dengan suatu badan atau instansi diperbolehkan untuk meminta informasi atau keterangan data tentang keuangan nasabah yang bersangkutan sesuai dengan ketentuan peerundang-undangan yang berlaku.

${ }^{12}$ Hermansyah, Hukum Perbankan Nasional Indonesia, Kencana Prenada Media Group, Jakarta: hlm. 131-132

${ }^{13}$ Ibid, hlm.132-133 
Berbeda dengan hal tersebut, dalam ketentuan rahasia bank menurut hukum Inggris merupakan kewajiban perdata atau kewajiban kontraktual, maka pengungkapan-nya yang dilakukan oleh bank berdasarkan persetujuan nasabah sebagai pihak dalam perjanjian bukanlah tindakan ingkar janji (default). Namun, dalam hal kewajiban rahasia bank itu bukan merupakan kewa-jiban perdata, tetapi kewajiban pidana, maka terdapat unsur delik, yakni unsur tindak pidana rahasia bank. ${ }^{14}$ Dengan tanpa permintaan tertulis atau persetujuan tertulis dari nasabah sebagai pihak dari transaksi keuangan bank merupakan unsur dari tindak pidana yang bersangkutan. Dengan kata lain, apabila memang ada permintaan atau per-setujuan tertulis dari nasabah agar bank mengungkapkan keadaan keuangannya, maka tidak dapat dianggap telah terjadi tindak pidana pengungkapan rahasia bank. ${ }^{15}$

Hal yang masih rancu adalah apakah kepentingan umum dapat dikecualikan dari ketentuan rahasia bank. Pengaturan masalah ini juga belum tercakup dalam UndangUndang Perbankan. Para pakar mengata-kan, bahwa ada atau tidaknya kepentingan umum tidak dapat ditentukan sendiri oleh bank, tetapi harus ditentukan oleh penga dilan secara kasuistis. Masalahnya, bagai-mana caranya mendapatkan pendapat pengadilan, dan sampai sejauh mana pendapat pengadilan (fatwa) mempunyai kekuatan hukum untuk dipatuhi oleh para hakim lain. Untuk menghindari perbedaan pandangan ini, tidak ada jalan lain kecuali harus diatur dengan undang-undang dengan memuat rincian secara detail jenis-jenis, kriteria kepentingan umum dan hal-hal lainnya yang merupakan bagian yang termasuk dalam kepentingan umum. ${ }^{16}$

Sebagai suatu badan usaha yang dipercayai oleh banyak masyarakat untuk menghimpun dan menyalurkan dananya, sudah sewajarnya bank memberikan jaminan perlindungan kepada nasabahnya berkenan dengan keadaan keuangan nasabah, yang lazimnya dinamakan dengan kerahasiaan bank. ${ }^{17}$ Cakupan rahasia dalam kegiatan

\footnotetext{
${ }^{14}$ Adrian Sutedi, op. cit., hlm. 14

${ }^{15}$ Ibid., hlm. 14-15.

${ }^{16}$ Ibid., hlm. 15.

${ }^{17}$ Rachmadi Usman, 2003, Aspek-Aspek Hukum Perbankan di Indonesia, PT Gramedia Pustaka Utama, Jakarta: hlm. 153.
} 
usaha perbankan syariah diatur dalam ketentuan dalam Pasal 41 Undang-Undang Nomor 21 Tahun 2008 tentang Perbankan Syariah yang menentukan sebagai berikut: Bank dan pihak terafiliasi wajib merahasia-kan keterangan mengenai nasabah penyim-pan dan simpanannya serta nasabah inves-tor dan investasinya.

Sejalan dengan ketentuan dalam Pasal 41 UUPS, sebelumnya ketentuan dalam Pasal 1 (14) UUPS merumuskan pengertian rahasia bank dalam kegiatan usaha perbankan syariah, yaitu: Rahasia bank adalah segala sesuatu yang berhubungan dengan keterangan mengenai nasabah penyimpan dan simpanannya serta nasabah dan investor dan investasinya.

Dengan demikian, berdasarkan pe-ngertian rahasia bank sebagaimana ter-cantum dalam ketentuan Pasal 1 Angka 14 UUPS, kemudian dihubungkan dengan ketentuan dalam Pasal 41 UUPS, maka jelas bahwa pengertian dan cakupan rahasia bank dalam kegiatan usaha perbankan syariah dibatasi, di antaranya:

a) Menyangkut segala sesuatu yang ber-hubungan dengan keterangan mengenai nasabah penyimpan dan simpanannya serta nasabah investor dan investasinya;

b) Pada dasarnya bank dan pihak terafiliasi berkewajiban memegang teguh kerahasiaan keterangan mengenai nasabah penyimpan dan simpanannya dan nasa-bah investor dan investasinya, kecuali hal itu tidak dilarang oleh undang-undang;

c) Karena kepentingan tertentu, informasi mengenai segala sesuatu yang berhubungan dengan keterangan mengenai nasabah penyimpan beserta dengan simpanannya dan nasabah investor be-serta dengan investasinya dapat dibuka.

Pengertian dan cakupan rahasia bank dalam kegiatan usaha perbankan syariah sebagaimana dikemukakan di atas sejalan dengan pengertian dan cakupan rahasia dalam kegiatan usaha perbankan konven-sional sebagaimana diatur dalam UUP, bahwa ketentuan rahasia bank yang semula mencakup nasabah kreditor dan debitor, telah dibatasi hanya menyangkut nasabah penyimpan dana dan simpanannya.

Sebelumnya berdasarkan Undang-Undang Nomor 7 Tahun 1992, bahwa ruang lingkup rahasia bank meliputi dana simpa-nan nasabah (nasabah kreditor) dan juga kredit yang diterima oleh nasabah (nasabah debitor), tetapi dewasa ini berdasarkan 
Undang-Undang Nomor 10 Tahun 1998, ruang lingkup rahasia bank terbatas hanya terhadap identitas nasabah penyimpan di samping keadaan simpanan nasabah yang bersangkutan. Ini berarti yang dilindungi rahasia bank tidak hanya menyangkut simpanannya saja, melainkan juga meliputi identitas nasabah penyimpannya.

Bank syariah sebagai lembaga inter-mediasi dalam melaksanakan kegiatan usahanya senantiasa bertumpu pada unsur ke-percayaan masyarakat, terutama kepercayaan nasabah penyimpan dana yang menem-patkan simpanannya dan nasabah investor yang menempatkan dana di Bank Syariah. Sebagai lembaga kepercayaan, maka Bank Syariah dan pihak terafiliasi diwajibkan untuk merahasiakan segala sesuatu yang berhubungan dengan keterangan mengenai nasabah penyimpan dan simpanannya dan nasabah investor dan investasinya berada pada Bank Syariah. Dengan demikian rahasia bank diperlukan sebagai salah satu faktor untuk menjaga kepercayaan nasabah penyimpan dan simpanannya serta nasabah investor dan investasinya.

Ketentuan rahasia bank, mula-mula diatur dalam Undang-Undang Nomor 7 Tahun 1992 sebagai pengganti Undang-Undang Nomor 14 Tahun 1967, yang kemudian diubah dengan Undang-Undang Nomor 10 Tahun 1998. Namun sebelumnya, ketentuan rahasia bank ini diatur dalam Undang-Undang Nomor 23 Prp Tahun 1960 tentang Rahasi Bank. Bila dibandingkan terdapat rumusan pengertian rahasia bank yang berbeda antara Undang-Undang Nomor 7 Tahun 1992 dengan Undang-Undang Nomor 10 Tahun 1998. Semula pengertian rahasia bank diberikan rumusan sebagaimana tersebut dalam ketentuan Pasal 1 Angka 16 Undang-Undang Nomor 7 Tahun 1992, yaitu:Rahasia bank adalah segala sesuatu yang berhubungan dengan keuangan dan hal-hal lain dari nasabah bank yang menurut kelaziman dunia perbankan wajib dirahasiakan.

Kemudian dalam ketentuan Pasal 40 Ayat (1) Undang-Undang Nomor 7 Tahun 1992 menyatakan, bahwa: Bank dilarang memberikan keterangan yang tercatat pada bank tentang keadaan keuangan dan hal-hal lain dari nasabahnya, yang wajib dirahasiakan oleh bank menurut keaziman dalam dunia perbankan, kecuali dalam hal sebagaimana dimaksud dalam Pasal 41, 42, 43 dan 44. 
Sementara itu penjelasan atas Pasal 40 ayat (1) Undang-Undang Nomor 7 Tahun 1992 menguraikan sebagai berikut: Kela-ziman wajib dirahasiakan oleh bank adalah seluruh data dan informasi mengenai segala sesuatu yang berhubungan dengan keuangan dan hal-hal lain dari orang atau badan yang diketahui oleh bank karena kegiatan usahanya.

Berdasarkan ketentuan dalam Pasal 1 angka 16 dan Pasal 40 ayat (1) UndangUndang Nomor 7 Tahun 1992 serta di-hubungkan dengan penjelasannya seperti dikemukakan di atas serta dihubungkan lagi dengan penjelasan Pasal 40 ayat (1) dalam kata-kata "kerahasiaan itu diperlukan untuk kepentingan bank sendiri yang memerlukan kepercayaan masyarakat yang menyimpan uangnya di bank", maka dapat disimpulkan bahwa lingkup rahasia bank itu mencakup simpanan nasabah.

Namun bila menyimak kata-kata berikutnya dari penjelasan atas Pasal 40 ayat (1), yaitu "masyarakat hanya akan mempercayakan uangnya kepada bank atau memanfaatkan jasa bank apabila dari bank ada jaminan bahwa pengetahuan bank tentang simpanan dan keadaan keuangan nasabah tidak akan disalahgunakan, maka dapat disimpulkan bahwa lingkup rahasia bank bukan hanya menyangkut keadaan keuangan dari nasabah yang menyimpan dana pada bank saja, melainkan pula nasabah lainnya yang menggunakan atau memanfaatkan jasa perbankan selain jasa penyimpanan dana.

Ini berarti berdasarkan Undang-Undang Nomor 7 Tahun 1992, yang dilindungi oleh ketentuan kerahasiaan bank, baik nasabah debitu maupun nasabah kreditor bank serta nasabah bank lainnya yang juga menggunakan atau memanfaatkan layanan jasa bank. Demikian pula yang dirahasiakan tidak terbatas hanya menyang-kut data dan informasi mengenai segala sesuatu yang berhubungan dengan keuangan pada bank yang bersangkutan, melainkan termasuk hal-hal lain dan orang atau badan yang diketahui oleh bank karena kegiatan usahanya, yang wajib pula untuk dirahasia-kan. ${ }^{18}$

${ }^{18}$ Djoni S. Gozali dan Rachmadi Usman, 2008, Buku Ajar Hukum Perbankan Nasional, Fakultas Hukum Universitas Lambung Mangkurat, Banjarmasin: hlm. 328-329. 
Masyarakat merasa tidak puas atas rumusan rahasia bank sebagaimana dirumuskan dalam Pasal 40 ayat (1) Undang-Undang Nomor 7 Tahun 1992, di mana rumusan itu terlalu jauh, karena sampai mencakup kredit bank yang diberikan kepada nasabah. Masyarakat berpendapat bahwa seyogyanya lingkup rahasia bank hanya meliputi dana simpanan nasabah saja (pasiva bank) dan keterangan yang menyangkut penyimpanan nya. Lingkup rahasia bank yang meliputi kredit yang diterima oleh nasabah (aktiva bank), dirasakan oleh masyarakat sebagai pemasungan hak masyarakat untuk mengetahui kredit-kredit macet perbankan yang sangat mempengaruhi kesehatan perbankan. ${ }^{19}$

Sehubung dengan itu, rumusan dan ruang lingkup kerahasiaan bank telah diubah dengan Undang-Undang Nomor 10 Tahun 1998, yang dirumuskan terdapat dalam ketentuan Pasal 1 angka 28 Undang-Undang Nomor 7 Tahun 1992 sebagaimana telah diubah dengan Undang-Undang Nomor 10 Tahun 1998, yaitu "Rahasia bank adalah segala sesuatu yang berhubungan dengan keterangan mengenai nasabah penyimpan dan simpanannya".

Demikian pula ketentuan dalam Pasal 40 ayat (1) Undang-Undang Nomor 7 Tahun 1992 juga mengalami perubahan dengan rumusan yang baru sebagaimana termuat dalam Pasal 40 ayat (1) Undang-Undang Nomor 10 Tahun 1998, sebagai berikut: Bank wajib merahasiakan keterangan mengenai nasabah penyimpan dan simpanannya, kecuali dalam hal sebagai-mana dimaksud dalam Pasal 41, 41A, 42, 43, 44, dan $44 A$.

Sementara itu, penjelasan atas Pasal 40 ayat (1) Undang-Undang Nomor 7 Tahun 1992 sebagaimana telah diubah dengan Undang-Undang Nomor 10 Tahun 1998 antara lain menyatakan, bahwa: Apabila nasabah bank adalah nasabah penyimpan yang sekaligus juga sebagai nasabah debitur, bank wajib tetap merahasiakan keterangan tentang nasabah dalam kedu-dukannya sebagai nasabah penyimpan. Keterangan

\footnotetext{
${ }^{19}$ Sutan Remy Sjahdeini, op. cit., hlm. 34.
} 
mengenai nasabah selain sebagai nasabah penyimpan, bukan meru-pakan keterangan yang wajib dirahasiakan bank.

Dari ketentuan di atas, dapat diketahui kalau ruang lingkup rahasia dibatasi atau dipersempit, yaitu:

a) Menyangkut keterangan mengenai nasa-bah penyimpan dan simpanannya. Ini berarti tidak termasuk keterangan men genai nasabah debitur dan pinja-mannya;

b) Pada dasarnya bank dan pihak terafiliasi berkewajiban memegang teguh kerahasiaan keterangan tersebut, kecuali hal itu tidak dilarang oleh undang-undang;

c) Situasi tertentu dalam mana informasi mengenai nasabah penyimpan peserta dengan simpanannya dibolehkan, atau dibenarkan saja dibeberkan oleh pihak yang terkena larangan jika informasi tersebut tergolong pada informasi yang dikecualikan atau informasi nasabah penyimpan dan simpanannya tidak termasuk dalam kualifikasi kerahasiaan bank. ${ }^{20}$

Dengan demikian Undang-Undang Nomor 7 Tahun 1992 sebagaimana telah diubah dengan Undang-Undang Nomor 10 Tahun 1998 telah membatasi atau mempersempit ruang lingkup rahasia bank hanya berhubungan dengan nasabah penyimpan dana (nasabah kreditor) dan simpanannya dan selebihnya yang berhubungan dengan nasabah peminjam dana (nasabah debitur) dan kredit tidak termasuk yang wajib dirahasiakan oleh bank. Sebenarnya peru-bahan ketentuan rahasia bank ini sangat dilematis di dalam praktiknya. Kalau nama-nama debitur boleh diumumkan oleh bank hanya untuk diketahui masyarakat umum, karena tindakan mengumumkan tersebut tidak dilarang oleh Undang-Undang Nomor 10 Tahun 1998, hal tersebut akan dimanfaat-kan oleh kawan-kawan dagangnya untuk menjatuhkan usahanya, sehingga perusaha-an besar akan berupaya keras untuk meng-usahakan kredit dari bank-bank di luar negeri untuk menghindarkan diumumkannya nama perusahaan yang bersangkutan. Kalau hal ini sampai terjadi, akan merugikan perbankan nasional. ${ }^{21}$

20 Djoni S. Gozali dan Rachmadi Usman, op. cit., hlm. 330.

21 Adrian Sutedi, op. cit., hlm. 8. 


\section{PENGECUALIAN RAHASIA BANK PADA PERBANKAN SYARIAH}

Undang-Undang Nomor 21 Tahun 2008 tentang Perbankan Syariah secara limitatif menentukan pengecualian atas berlakunya ketentuan rahasia bank dalam kegiatan usaha pebankan syariah. Penge-cualian ketentuan rahasia bank dalam kegiatan usaha perbankan syariah dimaksud diatur dalam ketentuan Pasal 42 sampai dengan Pasal 48 Undang-Undang Nomor 21 Tahun 2008, yang menetapkan sebagai berikut.

\section{Pasal 42}

(1) Untuk kepentingan penyidikan pidana perpajakan, pimpinan Bank Indonesia atas permintaan Menteri Keuangan berwenang mengeluarkan perintah tertulis kepada bank agar mem-berikan keterangan dan memper-lihatkan bukti tertulis serta surat mengenai keadaan keuangan Nasa-bah Penyimpan atau Nasabah Invetor tertentu kepada pejabat pajak.

(2) Perintah tertulis sebagaimana dimaksud ayat (1) harus menyebutkan mana penjabat pajak, nama nasabah wajib pajak, dan kasus yang dikehen-daki keterangannya.

\section{Pasal 43}

(1) Untuk kepentingan peradilan dalam perkara pidana, pimpinan Bank Indonesia dapat memberikan izin kepada polisi, jaksa, hakim, atau penyidik lain yang diberi wewenang berdasarkan undang-undang untuk memperoleh keterangan dari bank mengenai simpanan atau investasi tersangka atau terdakwa pada Bank.

(2) Izin sebagaimana dimaksud pada ayat (1) diberikan secara tertulis atas permintaan tertulis dari kepala Kepo-lisian Negara Republik Indonesia, Jaksa Agung, Ketua Mahkamah Agung, atau pimpinan instansi yang diberi wewenang untuk melakukan penyidikan

Permintaan sebagaimana dimaksud pada ayat (2) harus menyebutkan nama dan jabatan penyidik, jaksa, atau hakim, nama tersangka atau terdakwa, alasan 
diperlukannya kete-rangan, dan hubungan perkara pidana yang bersangkutan dengan keterangan yang diperlukan

\section{Pasal 44}

Bank wajib memberikan keterangan sebagaimana dimaksud dalam Pasal 42 dan Pasal 43.

\section{Pasal 45}

Dalam perkara perdata antara bank dan nasabahnya, direksi bank yang bersangkutan dapat menginformasikan kepada pengadilan tentang keadaan keuangan nasabah yang bersangkutan dan memberi-kan keterangan lain yang relevan dengan perkara tersebut.

\section{Pasal 46}

(1) Dalam rangka tukar-menukar infor-masi antarbank, direksi Bank dapat memberi tahukan keadaan keuangan Nasabahnya kepada bank lain.

(2) Ketentuan mengenai tukar-menukar informasi sebagaimana dimaksud pada ayat (1) diatur dalam Peraturan Bank Indonesia (PBI)

\section{Pasal 47}

Atas permintaan, persetujuan, atau kuasa dari nasabah penyimpan atau nasabah investor yang dibuat secara tertulis, bank wajib memberikan keterangan mengenai simpanan nasabah penyimpan dan nasabah investor pada bank yang bersangkutan kepada pihak yang ditunjuk oleh nasabah penyimpan atau nasabah investor tersebut.

\section{Pasal 48}

Dalam hal nasabah penyimpan atau nasabah investor telah meninggal dunia, ahli waris yang sah dari nasabah penyimpan atau nasabah investor yang bersangkutan berhak memperoleh keterangan mengenai simpanan nasabah penyimpan atau nasabah investor tersebut. 
Dari pasal-pasal tersebut, dapat disimpulkan bahwa Undang-Undang Nomor 21 Tahun 2008 memberikan pengecualian dapat dibukanya informasi rahasia bank terhadap 6 (enam) hal, artinya di luar 6 (enam) hal yang dikecualikan tersebut tidak termasuk sebagai dikecualikan dari kewajiban rahasian bank dalam kegiatan usaha perbankan syariah. Perngecualian berlakunya atas rahasia bank dalam kegiatan usaha perbankan syariah dimaksud meliputi:

1) Untuk kepentingan penyidikan pidana perpajakan diberikan pengecualian kepada pejabat pajak berdasarkan perintah tertulis pimpinan bank Indonesia atau permintaan menteri keuangan (Pasal 42);

2) Untuk kepentingan peradilan dalam perkara pidana diberikan pengecualian kepada polisi, jaksa, hakim atau penyidik lain yang diberi wewenang berdasarkan undangundang yang bedasarkan izin tertulis pimpinan bank indonesia atas permintaan kepala kepolisian, jaksa agung, dan ketua mahkamah agung republik indonesia atau pimpinan instansi yang diberikan wewenang untuk melakukan penyidikan (Pasal 43);

3) Untuk kepentingan perkara perdata antara bank dengan nasabahnya diberikan pengecualian kepada direksi bank yang besangkutan tanpa harus memperoleh izin pimpinan bank Indonesia (Pasal 45);

4) Dalam rangka tukar-menukar informasi antar bank diberikan pengecualian kepada direksi bank tanpa harus memperoleh izin pimpinan bank Indonesia (46);

5) Atas persetujuan, permintaan atau kuasa dari Nasabah penyimpan atau nasabah Investor dapat diberikan pengecualian secara tertulis kepada pihak yang di tujukan oleh Nasabah Penyimpan atau Nasabah Investor (47);

6) Adanya ahli waris yang sah untuk memperoleh keterangan mengenai simpanan nasabah (Pasal 48).

Dengan demikian, ketentuan rahasia bank dalam perbankan syariah dalam hal tertentu dapat dibuka atau dilanggar. Undang-Undang Nomor 21 Tahun 2008 telah memberikan pengecualian atau disclosure rahasia bank dalam kegiatan usaha perbankan syariah sebagaimana tertuang dalam Tabel berikut ini. 


\section{Pengecualian-Pengecualian Terhadap Ketentuan Rahasia Bank}

dalam Perbankan Syariah

\begin{tabular}{|c|c|c|c|c|}
\hline No. & Kepentingan & Permohonan izin & Pemberi izin & Dasar hukum \\
\hline 1. & $\begin{array}{l}\text { Penyidikan } \\
\text { pidana } \\
\text { perpajakan }\end{array}$ & Menteri keuangan & $\begin{array}{l}\text { Pimpinan bank } \\
\text { indonesia }\end{array}$ & Pasal 42 \\
\hline 2. & $\begin{array}{l}\text { Peradilan dalam } \\
\text { perkara pidana }\end{array}$ & $\begin{array}{lr}\text { Kapolri, } & \text { Jaksa } \\
\text { Agung, } & \text { Ketua } \\
\text { Mahkamah } & \\
\text { Agung, } & \text { dan } \\
\text { Pimpinan } & \text { Instansi } \\
\text { yang } & \text { diberi } \\
\text { wewenang } & \text { untuk } \\
\text { melakukan } & \\
\text { penyidikan } & \end{array}$ & $\begin{array}{l}\text { Pimpinan Bank } \\
\text { Indonesia }\end{array}$ & Pasal 43 \\
\hline 3. & $\begin{array}{lr}\text { Perkara } & \text { perdata } \\
\text { antara } & \text { Bank } \\
\text { dengan } & \text { Nasabah } \\
\text { Bank } & \text { yang } \\
\text { bersangkutan }\end{array}$ & Pengadilan & $\begin{array}{l}\text { Direksi Bank } \\
\text { yang } \\
\text { bersangkutan }\end{array}$ & Pasal 45 \\
\hline 4. & $\begin{array}{l}\text { Tukar-menukar } \\
\text { informasi antar } \\
\text { Bank }\end{array}$ & Bank lain & $\begin{array}{l}\text { Direksi Bank } \\
\text { yang } \\
\text { bersangkutan }\end{array}$ & Pasal 46 \\
\hline 5. & $\begin{array}{l}\text { Atas permintaan, } \\
\text { persetujuan atau } \\
\text { kuasa } \\
\text { nasabah } \\
\text { penyimpan atau } \\
\text { nasabah investor }\end{array}$ & $\begin{array}{l}\text { Nasabah } \\
\text { penyimpan atau } \\
\text { nasabah investor } \\
\text { yang bersangkutan }\end{array}$ & $\begin{array}{l}\text { Bank yang } \\
\text { bersangkutan }\end{array}$ & Pasal 47 \\
\hline 6. & $\begin{array}{l}\text { Memperoleh } \\
\text { keterangan } \\
\text { mengenai } \\
\text { simpanan } \\
\text { nasabah }\end{array}$ & $\begin{array}{l}\text { Ahli waris yang } \\
\text { sah }\end{array}$ & $\begin{array}{l}\text { Bank yang } \\
\text { bersangkutan }\end{array}$ & Pasal 48 \\
\hline
\end{tabular}

Sumber: Diolah dari Undang-Undang Nomor 21 Tahun 2008

Pada prinsipnya wajib memegang teguh dan menjaga kerahasiaan mengenai keadaan keuangan nasabah penyimpan dan simpanannya serta nasabah investor dan investasinya, namun dalam keadaan tertentu sebagaimana disebutkan dalam ketentuan 
Pasal-Pasal 42, 43, 45, 46, 47 dan 48 Undang-Undang Nomor 21 Tahun 2008, bahwa bank syariah dimungkinkan untuk memberikan data dan informasi mengenai segala sesuatu yang berhubungan dengan keuangan dan hal-hal lain dari nasabah penyimpan dan simpanannya serta nasabah investor dengan investasinya kepada pihak tertentu atas izin Pimpinan Bank Indonesia, Direksi bank yang bersangkutan, atau bank yang bersangkutan dalam hal-hal berikut.

\section{Untuk Kepentingan Penyidikan Pidana Perpajakan}

Pengaturan pengecualian atas keraha-siaan bank untuk kepentingan penyidikan pidana perpajakan dalam kegiatan usaha perbankan syariah dapat dijumpai dalam ketentuan Pasal 42 UUPS, yang merupakan disclosure atas paksaan hukum (under compulsion of law). Ketentuan dalam Pasal 42 UUPS menetapkan, bahwa untuk kepentingan penyidikan pidana perpajakan, kerahasiaan bank dapat dikesampingkan guna mengetahui keadaan keuangan sese-orang yang kebetulan menjadi nasabah penyimpan atau nasabah investor tertentu pada suatu bank syariah, dengan ketentuan berikut:

a. Menteri keuangan meminta pimpinan Bank Indonesia sesuai wewenangnya mengeluarkan perintah tertulis kepada Bank Syariah yang bersangkutan.

b. Isinya:

(1) Memberikan keterangan pada peja-bat pajak;

(2) Memperlihatkan bukti tertulis ke-pada pejabat pajak; dan

(3) Surat mengenai keadaan keuangan nasabah penyimpan atau nasabah investor tertentu kepada pejabat pajak.

c. Persyaratan:

(1) Perintah dibuat secara tertulis;

(2) Yang menyebutkan nama pejabat, nasabah wajib pajak;

(3) Kasus yang dikehendaki keterangan-nya.

Pengecualian dalam ketentuan Pasal 42 UUPS didasarkan atas kepentingan, masalah perpajakan berkaitan dengan kepen-tingan negara. 


\section{Untuk Kepentingan Peradilan dalam Perkara Pidana}

Pengecualian untuk kepentingan per-adilan dalam perkara pidana merupakan pengecualian atas paksaan hukum, yang diatur dalam ketentuan Pasal 43 UUPS. Berdasarkan ketentuan dalam Pasal 43 UUPS, bahwa untuk kepentingan peradilan dalam perkara pidana atas permintaan tertulis dari Kepala Kepolisian, Jaksa Agung, Ketua Mahkamah Agung Republik Indonesia dan pimpinan Instansi yang diberi wewenang untuk melakukan penyidikan, kerahasiaan bank dapat dikecualikan. Polisi, jaksa, hakim atau penyidik lainnya dapat minta izin kepada Pimpinan Bank Indonesia untuk memperoleh keterangan dari bank mengenai simpanan atau investasi tersangka atau terdakwa yang ada pada suatu bank syariah. Izin dimaksud didapat melalui tata cara sebagaimana diatur dalam ketentuan Pasal 43 ayat (2) dan ayat (3) UUPS, yaitu sebagai berikut:

a. Atas permintaan tertulis dari:

(1) Kepala Polri dalam tahap penye-lidikan dan penyidikan;

(2) Jaksa Agung dalam tahap penun-tutan;

(3) Ketua Mahkamah Agung dalam tahap pemeriksaan di muka sidang pengadilan;

(4) Pimpinan instansi yang diberi wewenang untuk melakukan penyi-dikan, yaitu pimpinan departemen atau lembaga pemerintah nondepar-temen setingkat menteri dalam tahap penyelidikan dan penyidikan.

b. Pemberi izin: Pimpinan Bank Indonesia

c. Isinya:

(1) Memperoleh keterangan dari bank mengenai simpanan tersangka atau terdakwa;

(2) Memperoleh keterangan dari bank mengenai investasi tersangka atau terdakwa.

d. Persyaratan:

(1) Dibuat secara tertulis (dapat bentuk izin);

(2) Menyebutkan nama dan jabatan penyidik, jaksa atau hakim;

(3) Nama tersangka atau terdakwa; 
(4) Alasan diperlukannya keterangan;

(5) Hubungan perkara pidana yang bersangkutan dengan keterangan yang diperlukan.

Berbeda dengan UUP, maka UUPS memperluas pengaturan mengenai penyidik, yang tidak hanya terbatas pada jaksa atau polisi saja, melainkan penyidik lain dari instansi yang diberi wewenang untuk mela-kukan penyidikan berdasarkan undangundang. Artinya penyidik lain yang di luar dari penyidik jaksa dan polisi dapat pula meminta keterangan dari bank syariah mengenai simpanan atau investasi seseorang yang tersangkut peradilan dalam perkara pidana.

Demikian pula yang menjadi dasar disclosure kerahasiaan bank syariah sebagaimana diatur dalam ketentuan Pasal 43 UUPS didasarkan pada kepentingan umum. Prinsip kerahasiaan bank yang bertujuan untuk melindungi kepentingan individu seorang nasabah, dikorbankan demi menyeimbang-kannya dengan kepentingan masyarakat umum, yang dalam hal ini menyangkut penyelesaian perkara tindak pidana. Asas keseimbangannya mengutamakan perlin-dungan kepentingan umum di atas kepen-tingan individu. ${ }^{22}$

\section{Untuk Kepentingan Pemeriksaan dalam Perkara Perdata antara Bank} dengan Nasabahnya

Pengecualian ketiga atas rahasia bank dalam kegiatan usaha perbankan syariah berlaku adalah dalam hal kepentingan perkara perdata antara bank dan nasabah sebagaimana yang ditentukan dalam keten tuan Pasal 45 UUPS. Dari ketentuan dalam Pasal 45 UUPS dapat diketahui, bahwa pengecualian atas rahasia bank dalam perbankan syariah sebatas pada perkara perdata yang terjadi antara bank syariah dan nasabahnya.

Ketentuan dalam Pasal 45 UUPS mem-perkenankan bank syariah yang bersangkutan menginformasikan kepada pengadilan tentang keadaan keuangan nasabah yang

${ }^{22}$ M Yahya Harahap, 1997, Beberapa Tinjauan tentang Permasalahan Hukum Buku Kedua, PT Citra Aditya Bakti, Bandung: hlm. 224. 
bersangkutan dan memberikan keterangan lain yang relevan dengan perkara yang diajukan kepada pengadilan, dengan per-syaratan:

a. Informasi dimaksudkan menyangkut perkara perdata antara pihak bank dan nasabahnya;

b. Direksi bank yang bersangkutan dapat menginformasikan kepada pengadilan tentang keadaan keuangan nasabah yang bersangkutan dan keterangan lain yang relevan dengan perkara perdata antara bank dan nasabahnya;

c. Tidak perlu meminta izin dari Pimpinan Bank Indonesia, artinya sepanjang informasi dimaksud diperlukan, direksi bank yang bersangkutan dapat menginformasikan kepada pengadilan tentang keadaan keuangan nasabah yang ber-sangkutan dan memberikan keterangan lain yang relevan dengan perkara ter-sebut.

Pengecualian seperti ini dijumpai pula dalam ketentuan Pasal 43 UUP, yang juga membatasi pada sengketa atau perkara perdata yang terjadi antara bank dengan nasabahnya. Pasal ini memperkenankan bank konvensional menginformasikan ke-pada pengadilan tentang keadaan keuangan nasabah yang bersangkutan dan memberikan keterangan lain yang relevan dengan perkara yang diajukan kepada pengadilan, dengan persyaratan:

a. Bila hal tersebut menyangkut perkara perdata yang terjadi antara pihak bank dengan pihak nasabahnya;

Direksi bank yang bersangkutan dapat menginformasikan kepada pengadilan tentang keadaan keuangan nasabah yang dalam perkara perdata dengan dan keterangan lain yang berkaitan dengan perkara dengan banknya tersebut;

b. Pemberian informasi ini tanpa izin dari pimpinan Bank Indonesia, artinya pihak bank dapat dengan segera menginfor-masikan keadaan keuangan nasabahnya tanpa harus menunggu izin dari pim-pinan Bank Indonesia.

Pendirian yang dianut Pasal 43 ini sangat sempit sebab terbatas pada perkara perdata yang terjadi antara bank dan nasabahnya. Dengan batasan demikan, bank hanya diperbolehkan memberi informasi keadaan keuangan nasabah dalam hal bank 
menggugat nasabah atas alasan wanprestasi. Memang logis kalau bank mesti memberi informasi agar informasi itu landasan fundamentum petendi gugat. ${ }^{23}$ Sempitnya penerapan Pasal 43 dianggap sangat merugikan kepentingan masyarakat luas, terutama bagi kepentingan dunia bisnis. Pasal tersebut seolah-olah mengandung diskriminasi karena hanya melindungi kepentingan perusahaan perbankan saja dan tidak melindungi kepentingan perusahaan jenis lain dalam arti luas. Kalau bank yang bersengketa prinsip kerahasiaan banknya boleh dilanggar dan di luar itu tidak. Itu jelas tidak adil. Seolaholah, undang-undang tidak peduli terhadap kesengsaraan yang dialami masyarakat luas. Padahal banyak perusahaan dengan sengaja tidak membayar kewajiban (utang) kepada mitra bisnisnya di sektor distribusi, agen, atau kontraktor walaupun perushaanperusahaan itu aktivanya lancar (current assets) diberbagai bank. ${ }^{24}$

\section{Untuk Kepentingan Tukar-menukar Informasi Antarbank}

Pengecualian berikutnya atas rahasia bank dalam kegiatan usaha perbankan syariah berlaku dalam hal kepentingan tukar-menukar informasi antarbank sebagaimana ditentukan dalam ketentuan Pasal 46 UUPS. Dalam Pasal 46 UUPS ditetapkan, bahwa dalam rangka tukar-menukar infor-masi antarbank, direksi bank dapat memberitahukan keadaan keuangan nasabahnya kepada bank lain. Dengan merujuk kepeada ketentuan dalam Pasal 46 UUPS, maka direksi bank syariah dapat memberitahukan keadaan keuangan nasabah kepada bank syariah lainnya, yang dilakukan dalam rangka saling tukar-menukar informasi antarbank.

Sebelum ketentuan pengecualian atas rahasia bank dalam rangka tukar menukar informasi antarbank juga diatur dalam ketentuan Pasal 44 UUP, yang menetapkan bahwa dalam rangka tukar-menukar infor-masi antarbank, direksi bank dapat memberikan informasi mengenai keadaan keuangan nasabah kepada bank lain. Tukarmenukar informasi antarbank dilakukan untuk memperlancar dan mengamankan

\footnotetext{
${ }^{23}$ Ibid., hlm. 225.

${ }^{24}$ Ibid., hlm. 226.
} 
kegiatan usaha bank, antar lain guna mencegah pemberian kredit rangkap serta mengetahui keadaan dan statusnya dari bank yang lain, sehingga bank dapat menilai tingkat resiko yang dihadapi sebelum melakukan transaksi dengan nasabah atau dengan bank lain.

Ketentuan dalam Pasal 44 UUP sangat diskriminatif, hanya sebatas antar bank saja dengan tidak memberikan peluang kepada masyarakat yang berkecimpung dalam dunia bisnis. Padahal dunia bisnis dalam arti luas sangat memerlukan informasi data keadaan keuangan yang sebenarnya dari suatu perusahaan yang hendak bermitra dengannya. Sepantasnya memang jika sbuah perusahaan atau masyarakat ingin mengetahui dengan pesis keadaan keuangan calon mitranya. ${ }^{25}$

\section{Adanya Permintaan, Persetujuan, atau Kuasa Tertulis dari Nasabah Penyimpan atau Nasabah Investor}

Pengecualian berikutnya atas rahasia bank dalam kegiatan usaha perbankan syariah berlaku dalam hal adanya permintaan, persetujuan, atau kuasa tertulis dari nasabah penyimpan atau nasabah inves-tor sebagaimana ditentukan dalam ketentuan Pasal 47 UUPS. Dalam Pasal 47 UUPS ditetapkan, bahwa bank syariah wajib memberikan keterangan mengenai simpanan nasabah penyimpan atau nasabah investor pada bank yang bersangkutan kepada pihak yang ditunjuk oleh nasabah penyimpan atau nasabah investor. Keterangan mengenai simpanan nasabah penyimpan atau nasabah investor tersebut akan diberikan oleh bank yang bersangkutan dengan persyaratan bilamana sebelumnya: adanya permintaan, persetujuan, atau kuasa dari nasabah penyimpan atau nasabah investor; dan dibuat secara tertulis yang ditujukan kepada bank syariah di mana nasabah penyimpan menempatkan dana atau nasabah investor menginvestasikan dana.

Sebelumnya pengecualian atas rahasia bank seperti ini ditentukan pula dalam ketentuan Pasal 44A yang merupakan ketentuan baru yang ditambahkan dalam

\footnotetext{
${ }^{25}$ Ibid., hlm. 227-228.
} 
Undang-Undang Nomor 10 Tahun 1998. Ketentuan dalam Pasal 44A ayat (1) UUP menetapkan, bahwa bank wajib memberikan keterangan mengenai simpanan nasabah penyimpan pada bank yang bersangkutan kepada pihak yang ditunjuk oleh nasabah penyimpan. Keterangan mengenai simpanan tersebut akan diberikan oleh bank yang bersangkutan dengan syarat bila sebelum-nya: ada permintaan, persetujuan, kuasa dari nasabah penyimpan dana; dan dibuat secara tertulis yang ditujukan kepada bank oleh nasabah penyimpan dana.

Kalau kita perhatikan, dasar penge-cualian kerahasiaan bank yang dicantumkan dalam ketentuan Pasal 44A ayat (1) UUP berkaitan dengan kepentingan nasabah penyimpan dana, bukan menyangkut kepen-tingan umum, kepentingan penyelesaian perkara, apalagi demi kepentingan bank itu sendiri. Kerahasiaan bank di sini boleh dibuka asalkan hal itu disetujui oleh nasabah penyimpan dananya atau kuasanya. Bank wajib membuka atau memberikan kete-rangan yang berkaitan dengan simpanan nasabah penyimpan dana, asalkan hal itu ada permintaan, disetujui atau dikuasakan oleh nasabah penyimpan dana kepadsa bank yang bersangkutan kepada pihak yang ditunjuk oleh nasabah penyimpan dana. ${ }^{26}$

\section{Adanya Ahli Waris yang Sah untuk Memperoleh Keterangan Mengenai Simpanan Nasabah}

Pengecualian terakhir atas rahasia bank dalam kegiatan usaha perbankan syariah berlaku dalam hal adanya ahli waris yang sah untuk memperoleh keterangan mengenai simpanan nasabah sebagaimana ditentukan dalam ketentuan Pasal 48 UUPS. Dalam ketentuan Pasal 48 UUPS ditetapkan, bahwa ahli waris yang sah dari nasabah penyimpan atau nasabah investor berhak memperoleh keterangan mengenai simpanan nasabah penyimpan atau nasabah investor dalam hal nasabah penyimpan atau nasabah investor telah meninggal dunia. Kalau diperhatikan, pengecualian atas rahasia bank ini

${ }^{26}$ Djoni S. Gozali dan Rachmadi Usman, op. cit., hlm. 339. 
didasarkan kepada kepentingan ahli waris dalam rangka penyelesaian pembagian harta kewarisan yang pewarisnya menjadi nasabah perbankan syariah.

Bagi perbankan konvensional, penge-cualian atas rahasia bank seperti ini diatur dalam ketentuan Pasal 44A ayat (2) UUP, yang menetapkan bahwa dalam hal nasabah penyimpan telah meninggal dunia, maka ahli waris yang sah dari nasabah penyimpan yang bersangkutan berhak memperoleh keterangan mengenai simpanan nasabah penyimpan tersebut. Dengan sendirinya bank berkewajiban memberikan keterangan mengenai simpanan nasabah penyimpan kepada ahli warisnya yang sah bila yang bersangkutan telah meninggal dunia dalam rangka untuk menyelesaikan pembagian harta kewarisan.

Bila dibandingkan dengan peraturan pengecualian atas rahasia bank dalam UUP, maka dalam UUPS tidak terdapat penga-turan pengecualian atas rahasia bank dalam kegiatan perbankan syariah berlaku dalam hal untuk kepentingan penyelesaian piutang bank yang telah diserahkan kepada Badan Urusan Piutang dan Lelang Negara (BUPLN) atau Panitia Urusan Piutang Negara (PUPN).

Pengecualian atas bank konvensional untuk kepentingan piutang yang sudah diserahkan kepada BUPLN/PUPN dimaksud telah diatur dalam ketentuan Pasal 41A yang merupakan tambahan ketentuan rahasia bank melalui Undang-Undang Nomor 10 Tahun 1998 atas Undang-Undang Nomor 7 Tahun 1992. Ketentuan dalam Pasal 41A UUP menetapkan bahwa untuk penyelesaian piutang bank yang sudah diserahkan kepada BUPLN/PUPN, Pimpinan Bank Indonesia memberikan izin kepada pejabat BUPLN/ PUPN untuk memperoleh keterangan dari bank mengenai simpanan nasabah debitur.

Izin untuk memperoleh keterangan dari bank mengenai simpanan nansabah debitur dimaksud dalam rangka penye-lesaian piutang yang sudah diserahkan kepada BUPLN/PUPN akan diberikan oleh Pimpinan Bank Indonesiadengan persyara-tan sebagai berikut.

a. Dilakukan atas permintaan tertulisdari Kepala BUPLN/Ketua PUPN dengan menyebutkan nama dan jabatan pejabat BUPLN/PUPN yang meminta keterang-an, 
nama nasabah debitur yang ber-sangkutan yang diperlukan keterangan, dan alasan diperlukan keterangan dari nasabah debitur tersebut.

b. Izin tersebut dengan sendirinya diberi-kan secara tertulis dengan menyebutkan nama dan jabatan pejabat BUPLN/ PUPN yang meminta keterangan, menyebutkan nama nasabah debitur yang akan dimintai keterangan berkaitan dengan piutang bank yang diserahkan kepada BUPLN/PUPN, serta mencan-tumkan keperluan keterangan tersebut dikaitkan dengan urusan penyelesaian piutang bank dengan nasabah debitur yang bersangkutan.

Kalau diteliti pengecualian atas rahasia untuk kepentingan piutang yang sudah diserahkan kepada BUPLN/PUPN tersebut, berkaitan dengan kepentingan bank itu sendiri (in the interest of the bank) untuk menjamin kelangsungannya dalam berusaha. $^{27}$

\section{PENUTUP}

Cakupan rahasia bank dalam kegiatan usaha perbankan syariah dibatasi, di antaranya:

a. Menyangkut segala sesuatu yang ber-hubungan dengan keterangan mengenai nasabah penyimpan dan simpanannya serta nasabah investor dan investasinya;

b. Pada dasarnya bank dan pihak terafiliasi berkewajiban memegang teguh kera-hasiaan keterangan mengenai nasabah penyimpan dan simpanannya dan nasa-bah investor dan investasinya, kecuali hal itu tidak dilarang oleh undang-undang;

c. Karena kepentingan tertentu, informasi mengenai segala sesuatu yang berhubungan dengan keterangan mengenai nasabah penyimpan beserta dengan simpanannya dan nasabah investor beserta dengan investasinya dapat dibuka.

\footnotetext{
${ }^{27}$ Ibid., hlm. 336.
} 
Pengecualian Rahasia Bank dalam Perbankan Syariah untuk kepentingan:

a. Untuk kepentingan penyidikan pidana perpajakan

b. Untuk kepentingan peradilan dalam per-kara pidana;

c. Untuk kepentingan pemeriksaan dalam perkara perdata;

d. Untuk kepentingan tukar-menukar infor-masi antarbank;

e. Adanya permintaan atau persetujuan atau kuasa tertulis dari nasabah atau nasabah investor; dan

f. Adanya Ahli Waris yang Sah untuk Memperoleh Keterangan Mengenai Simpanan Nasabah.

\section{DAFTAR PUSTAKA}

Supraptomo, Heru, 2005, Terobosan Hukum dalam Rahasia Bank, artikel dalam Jurnal Hukum Bisnis Volume..., Yayasan Pengembangan Hukum Bisnis, Jakarta.

Djumhana, Muhammad , 1996, Rahasia Bank (Ketentuan dan Penerapannya) di Indonesia, PT Citra Aditya Bakti, Bandung.

Sutedi, Andrian, 2007, Hukum Perbankan: Suatu Tinjauan Pencucian Uang, Merger, Likuidasi, dan Kepailitan, Sinar Grafika, Jakarta.

Hermansyah, 2005, Hukum Perbankan Nasional Indonesia, Kencana, Jakarta.

Soekanto, Soejono, 2006, Pengenalan Penelitian Hukum, Grafindo, Jakarta.

Sjahdeini, Sutan Remy, 2006, Rahasia Bank: Berbagai Masalah di Sekitarnya, dalam Hukum Perbankan, Program Pascasarjana Universitas Indonesia, Jakarta.

Djumhana, Muhammad , 1996, Rahasia Bank (Ketentuan dan Penerapannya) di Indonesia, PT Citra Aditya Bakti, Bandung.

Fuady,Munir, 1999, Hukum Perbankan Modern Buku Kesatu, PT Citra Aditya Bakti, Bandung.

Undang-Undang Nomor 10 Tahun 1998 tentang Perubahan Atas Undang-Undang Nomor 7 Tahun 1992 tentang Perbankan

Undang-Undang Nomor 21 Tahun 2008 tentang Perbankan Syariah. 
Muhamad Djumhana, 2012, Hukum Perbankan di Indonesia, Citra Aditya Bakti, Cetakan ke VI.

Hermansyah, Hukum Perbankan Nasional Indonesia, Kencana Prenada Media Group, Jakarta.

Rachmadi Usman, 2003, Aspek-Aspek Hukum Perbankan di Indonesia, PT Gramedia Pustaka Utama, Jakarta.

Djoni S. Gozali dan Rachmadi Usman, 2008, Buku Ajar Hukum Perbankan Nasional, Fakultas Hukum Universitas Lambung Mangkurat, Banjarmasin.

M Yahya Harahap, 1997, Beberapa Tinjauan tentang Permasalahan Hukum Buku Kedua, PT Citra Aditya Bakti, Bandung 